\title{
Quantifying the impact of off-road driving on root-area distribution in soils
}

\author{
Gerhardus P. Nortjé ${ }^{1 *}$, Wouter v. Hoven ${ }^{2}$, Michiel C. Laker ${ }^{3}$, \\ Johanna C. Jordaan ${ }^{4} \&$ Michelle A. Louw ${ }^{5}$ \\ ${ }^{1}$ Research Fellow, Department of Environmental Sciences, UNISA, P.O. Box 392, UNISA, 0003 South Africa \\ ${ }^{2}$ Emeritus Professor Wildlife Management, University of Pretoria, Private Bag X20, Hatfield, 0028 South Africa \\ ${ }^{3}$ Emeritus Professor of Soil Science, University of Pretoria, Private Bag X2O, Hatfield, 0028 South Africa \\ ${ }^{4}$ Research Consultant, Department of Statistics, University of Pretoria, Private Bag X20, Hatfield, 0028 South Africa \\ ${ }^{5}$ Research Assistant, Centre for Wildlife Management, University of Pretoria,Private Bag X20, Hatfield, 0028 South Africa
}

Received 22 Decemberl 2014. To authors for revision 16 April 2015. Accepted 2 October 2015

\begin{abstract}
Studies on the effects of off-road driving on soils were conducted in the Makuleke Contractual Park of the Kruger National Park. The studies were conducted on three different soils with different textures and soil compactibilities. Traffic pressure was applied with a game drive vehicle loaded with 10 sand bags, each weighing $70 \mathrm{~kg}$, plus the driver. This gave a total vehicle mass of $3795 \mathrm{~kg}$, simulating a vehicle fully laden with tourists. The results of the study reported here included comparing of the effects of four different tyre pressures on the root area distribution below each tyre pressure. At all sites, root density fractions under the tracks were reduced significantly at all tyre pressures, compared with the control values. Results indicated that root penetration percentage and root area distribution were reduced drastically as tyre pressure increased. Our work reaffirms previous research showing that higher tyre pressures cause higher sub-soil compaction than lower tyre pressures. Thus, driving with lower tyre pressures when driving off-road should be considered when developing management strategies for off-road driving in wildlife protected areas.
\end{abstract}

Key words: photographic image analysis, soil compaction, off-road driving, tyre pressure, penetration resistance, vehicle passes, root density, root area distribution.

\section{INTRODUCTION}

As part of the South African National Parks (SANParks) commercialization process in the Kruger National Park (KNP), concession areas were set aside for the exclusive use of private operators (Nortjé, 2005). The objective of the commercialization process is to broaden the tourism product of the KNP and, thereby, increase the revenue for the SANParks (Nortjé, 2005).

Concession operators are allowed certain tourist-attracting activities, including off-road driving (ORD), aimed at bringing tourists in close contact with members of the 'Big Five'. The term 'Big Five' comes from hunting traditions and refers to five of Africa's greatest wild animals: lion (Panthera leo), leopard (Panthera pardus), elephant (Loxodonta africana), buffalo (Syncerus caffer) and the two species of African rhinoceros, the black (Diceros bicornis) and the white rhinoceros (Ceratotherium simum). But such activities are often implemented without knowledge regarding the impacts of the

*To whom correspondence should be addressed.

E-mail: nortjegpn@absamail.co.za activities on the environment or the soils (Nortje et al., 2012; Nortjé, 2014). Certain principles and guidelines were set for practising ORD in the concession areas, but some of these guidelines and principles have not been tested.

The problem is that these off-road vehicles have detrimental impacts on the soil and vegetation. Studies on the impacts of tourists' activities on wildlife in Africa have been conducted by, amongst others, Onyeanusi (1986), Akama (1997, 1999), Bhandari (1998, 2000, 2014), Crawley (2000), Haenn (2000), Ondicho (2000), Ottichilo et al. (2000), Karanja et al. (2003) and Walpole et al. (2003).

Several studies have been conducted since the early 1960 s in the U.S.A., Australia and South Africa on the effects of soil compaction on plant growth. These studies have been reviewed by, amongst others, Taylor et al., (1966), Barley \& Greacen (1967), du Preez et al., (1979, 1981), Bennie \& Krynauw (1985), Martino \& Shaykewich (1993), Unger \& Kaspar (1994), Merotto \& Mundstock (1999), SASTA (2001) and Bengough 
et al. (2011). In these studies, the relationship between root penetration and soil strength as an indicator of soil compaction has been investigated.

For plants to derive benefits from water and nutrients in soil, plant roots must be able to reach them. Therefore, compaction of soil which prevents root penetration or reduces root elongation rates may reduce plant development and yields, because water and nutrients beneath the restricting zone are unavailable to the plants (Unger \& Kaspar, 1994; Bengough et al., 2011).

The objectives of this study were 1) to determine the effects of vehicle traffic on root development by comparing the root area distribution below off-road tracks at each of the following tyre pressures, 80 , 160,240 and $320 \mathrm{kPa}$, with those outside the tracks (controls) and 2) to evaluate a photographic image analysis method for quantifying these relationships.

\section{METHODS}

\section{Study area and trial sites}

Field experiments were initiated during March 2010 at three different sites in the Makuleke Contractual Park (MCP), in northern KNP, South Africa (Nortjé, 2014). The MCP is situated between the Limpopo and Luvuvhu Rivers (Fig. 1). This 24000-ha area is recognized as one of the most diverse and scenically attractive areas in the KNP and is called either the Pafuri triangle or the Makuleke Concession, because it is the ancestral home of the Makuleke people (Pafuri Factsheet, 2011).

The Makuleke area is the meeting point of a multitude of habitats, resulting in a region of incredibly rich biodiversity. The reasonably low annual rainfall of between 375-400 mm per year belies the fertility of the area which is by far the most diverse within the KNP, with more than $70 \%$ of the Park's bird, mammal, fish, amphibian, reptile and tree species being found here (Pafuri Factsheet, 2011). The concession has mild winters from May to September with occasional chilly evenings; however, summers are generally very hot.

The area is also exceptionally scenic. From the pans and floodplains of the Limpopo and Luvuvhu Rivers to the cool riverine forests along their banks, there are rugged kopjes covered in mopane (Colophospermum mopane), giant baobabs (Adansonia digitata) and charismatic commiphoras (Commiphora africana), gorges carved from ancient rock, acacia-shaded savanna

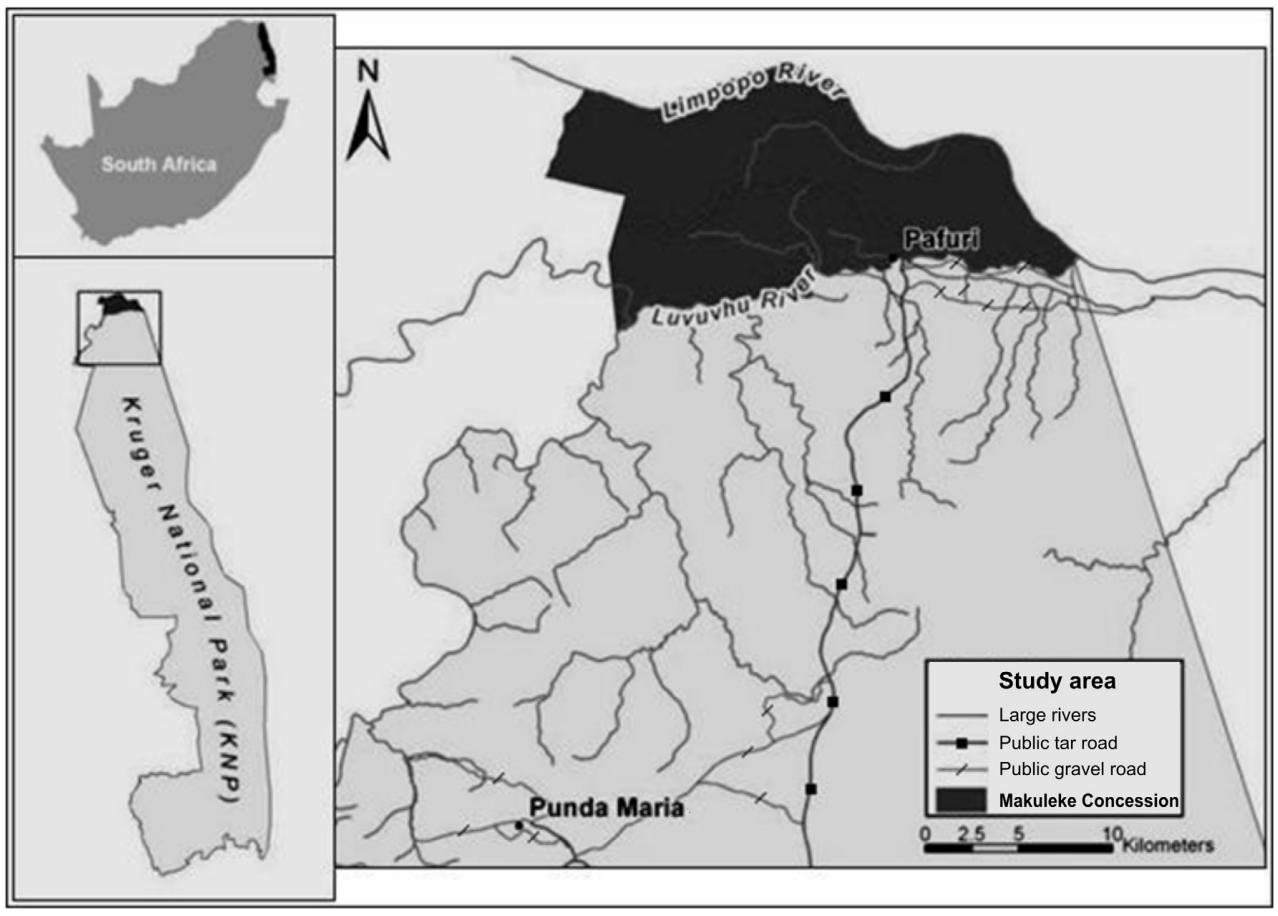

Fig. 1. Location of Makuleke Contractual Park in Kruger National Park, South Africa. 


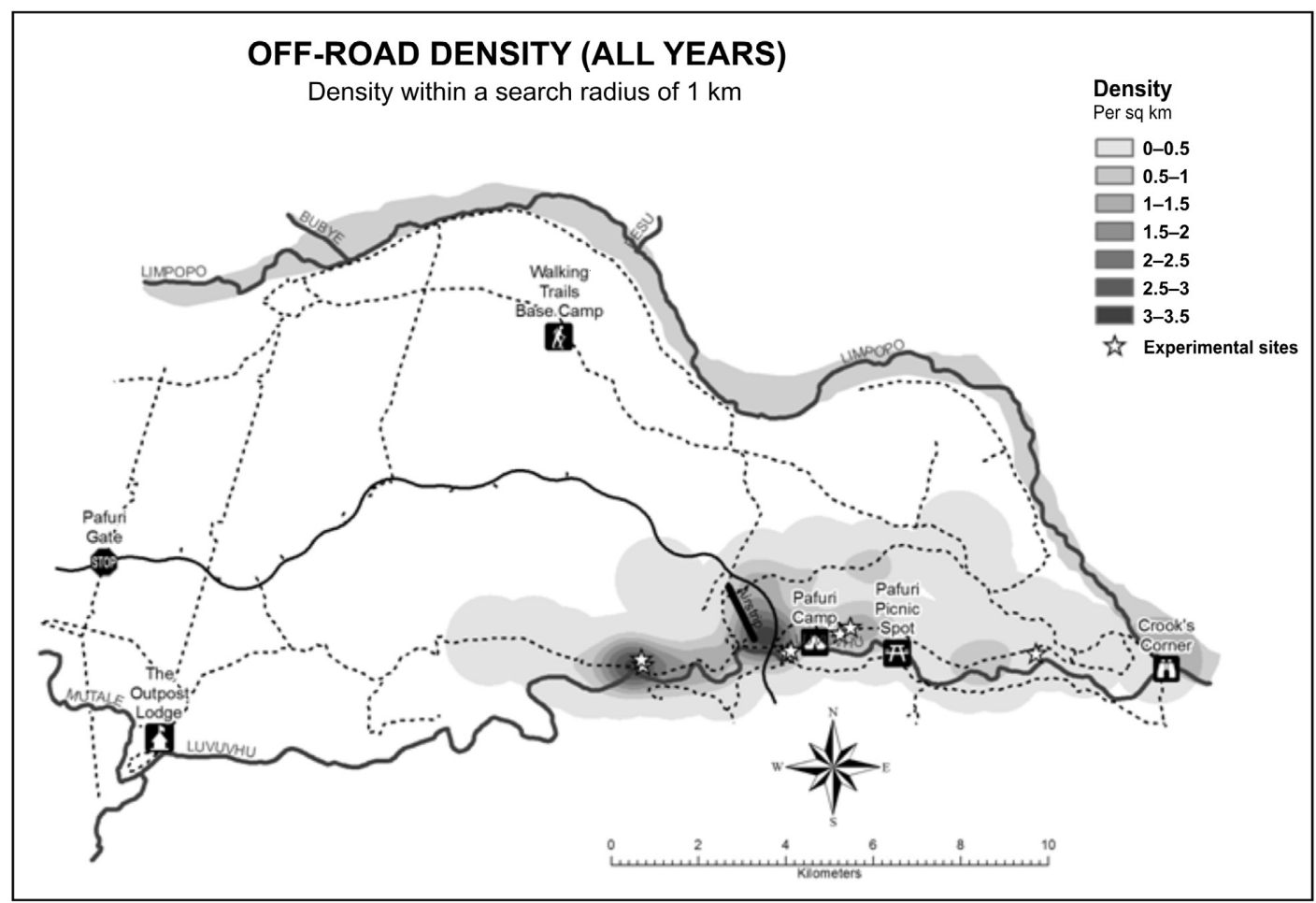

Fig. 2. Map indicating the frequencies of ORD in the different areas showing the three trial sites.

and the renowned fever tree (Acacia xanthophloea) forests. Many tree species reach the southern most extremity of their ranges here. The MCP part of the Pafuri Land System which consists of five landscapes (Gertenbach 1983): Punda Maria Sandveld on Cave Sandstone, Adansonia digitata/Colophospermum mopane Rugged Veld, Colophospermum mopane Shrubveld on Calcrete, Mixed Combretum spp./Colophospermum mopane Woodland and LimpopoLuvuvhu Flood Plains.

The trial sites were chosen by identifying the areas in which ORD occurred most (more than $90 \%$ of ORD incidents) and selecting a representative site in each of these (Fig. 2). This was conducted by analysing off-road data from previous animal sightings, for which ORD was approved. These sites were selected after one year of practising ORD in the area. They were also selected to represent the most important soil types in the specific areas. The three trial sites were Camp Site (Site 1), River Site (Site 2), and LW (Levuvhu West) Site (Site 3).

\section{Simulating ORD}

The vehicle used to simulate ORD situations was a typical game drive vehicle with a roof rack, having a vehicle mass of $3025 \mathrm{~kg}$. It was loaded with 10 sand bags averaging $70 \mathrm{~kg}$ per bag, representing the maximum number of passengers, plus the driver/guide. Thus, the total mass came to $3795 \mathrm{~kg}$.

The vehicle had $190 \mathrm{~mm}$ wide tyres and these tyres were all inflated to either 320, 240, 160 or $80 \mathrm{kPa}$ during testing. Game drive vehicles typically operate at a tyre pressure of $240 \mathrm{kPa}$. The vehicle was driven across each trial site at a steady speed of between 10 and $15 \mathrm{~km} / \mathrm{h}$ to produce sets of tracks which consisted of one, two and three vehicle passes. These passes were done for all tyre inflation pressures and were $10 \mathrm{~m}$ in distance. A diagrammatic representation of the trial layout is shown in Fig. 3. For each tyre pressure, the first pass of the vehicle was in the direction of the arrow. The second pass was in reverse, and the third pass again in the direction of the arrow.

\section{Measurement of soil moisture content}

The compaction trials were conducted for dry conditions during a low-rainfall period in March 2010. Gravimetric soil water content was deter- 

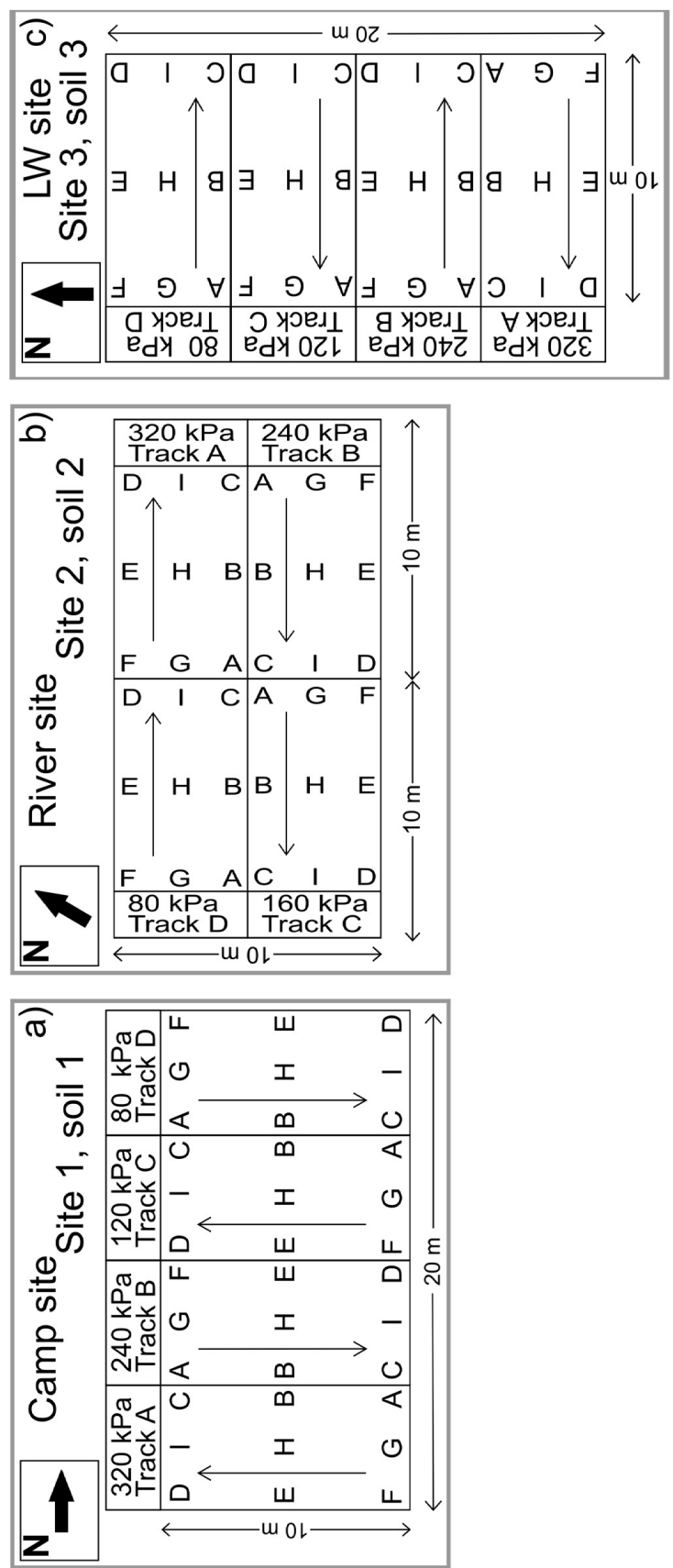
mined by taking representative $(400-450 \mathrm{~g})$ soil samples at different depths $(0-20,20-40$ and 40-60 $\mathrm{cm}$ ) before each experiment commenced. This was conducted early in the morning between 06:00 and 06:30 for all three trials for consistency. The soil samples were weighed on an electronic scale and then microwave dried for up to $10 \mathrm{~min}$ whilst weighing at $1 \mathrm{~min}$ intervals until a constant mass was obtained. We calculated soil water content values as a mass percentage per mass oven-dried soil, i.e. $\left.m_{w} \times 100\right) / m_{s}$ (Table1).

Field-determined field capacity, or the 'drained upper limit' (DUL), was used as the upper limit of water held by the soil (see Cassel et al., 1983; Annandale et al., 2011). Soil water content at field capacity for the study site was thus determined by initially wetting the soil to saturation and allowing the water to drain to a constant mass (negligible drainage rate).

\section{Quantifying root density distribution}

The method followed was a combination of the Profile Wall Method (Bohm,1979) and the Photographic Image Analysis by making use of ImageJ Software (Rasband, 2011; Bekker, 2007; Schneider et al., 2012; Plaza-Bonilla et al., 2012). These analyses were preferred to other methods that are often indicated in literature as being tedious and time-consuming.

Root density distribution determinations were done in the beginning of December 2010, 8.5 months after the ORD simulations were conducted in dry soil conditions. This was done to allow sufficient grass recovery for root density determination. In total, $218.2 \mathrm{~mm}$ of rain was measured between the ORD simulations in March 2010 and the root density distribution determinations. Soil profiles were excavated under each vehicle track representing tyre pressures of $80,160,240$ or $320 \mathrm{kPa}$ and at the control positions. Root density distribution was assessed for the grass species growing at the study sites three times for each treatment.

According to Bohm (1979), it is only necessary to remove a layer of soil $c .1 \mathrm{~cm}$ thick from the profile wall to expose the roots after excavation. For plants with fibrous root systems, a square of $5 \times 5 \mathrm{~cm}$ has proven satisfactory for studying grass root density distribution. The size of the grid (profile) in this study was 430 (depth) $\times 330 \mathrm{~mm}$ (horizontal), 4.23 times smaller than the $1000 \times$ $600 \mathrm{~mm}$ proposed by Bohm (1979). This was sufficient as it covered at least $150 \mathrm{~mm}$ on either side of the tyre tracks and included most grass roots. In addition, the grass roots were also limited to depths of less than $430 \mathrm{~mm}$ in this study.

A digital photograph of the exposed roots was taken at a set distance of $500 \mathrm{~mm}$ from each soil profile with a Canon 350D digital camera (8 megapixel, 18-55 mm lens). Photographs were analysed using the computer software ImageJ 1.33u (Rasband, 2011). The photographs were converted from a RGB colour type photograph to an 8-bit image. A threshold (upper threshold 255, lower threshold level 170-195) was assigned to the foreground colour (the yellow/white grass roots) and the remaining pixels to the background colour (soil surface), where after the photographs were converted to a black and white picture. Pixels not related to roots, including leaf material, rope, grid wire and grass litter (background noise) in the photographs were deleted from the pictures. The pictures were then computer analysed, and area fraction determined and recorded as a percentage root density (Bekker, 2007).

\section{Characteristics and properties of soils}

Camp Site (Site 1) and Levuvhu West (LW) Site (Site 3) are on soils of the Oakleaf form, and River Site (Site 2) on a soil of the Dundee form according to the South African soil classification system (Soil Classification Working Group, 1991). The Oakleaf soils are classified as Cambisols according to

Table 1. Gravimetric soil water content before experiment commenced (MCP, March 2010).

\begin{tabular}{|c|c|c|c|c|c|}
\hline \multirow[b]{2}{*}{ Soil depth $(\mathrm{cm})$ : } & \multicolumn{3}{|c|}{$\begin{array}{l}\text { Measured gravimetric soil water } \\
\text { content at sampling (\%) }\end{array}$} & \multicolumn{2}{|c|}{$\begin{array}{l}\text { Gravimetric water content } \\
\text { at field capacity (\%) }\end{array}$} \\
\hline & $0-20$ & $20-40$ & $40-60$ & $0-20$ & $20-60$ \\
\hline \multicolumn{6}{|l|}{ Site } \\
\hline Camp & 6.35 & 3.75 & 3.16 & 18.18 & 19.79 \\
\hline River & 3.31 & 3.76 & 4.32 & 14.80 & 8.34 \\
\hline LW & 7.56 & 6.73 & 5.35 & 19.13 & 21.09 \\
\hline
\end{tabular}


WRB (1998) and the Dundee soils as Fluvisols. The soils of Sites 1 and 3 are pedogenetically young soils in early stages of development on a large sub-recent river terrace (the second terrace) (Nortjé et al., 2012). There is a clay increase from the topsoil to the weakly structured subsoil. The soil of Site 2 with alluvial stratifications is on the lowest terrace next to the river, presently being affected by sediment deposition. There were important differences between the three soils regarding their chemical and physical characteristics (Nortjé et al., 2012).

Particle size distribution (soil texture) was determined with a combination of sieve and pipette methods (AgriLASA, 1990; Jackson, 1958). The sand was fractioned by dry sieving, and the clay and silt fractions were determined by the pipette method. Compactibility was determined with the use of the soil compactibility diagram developed by van der Watt (1969) (Table 2).

From the multisieve analyses, the degree of sorting of the sand fraction was determined, since this has effects on soil physical conditions (Table 3 ) and phi-value curves were constructed (Fig.4).

\section{Clay mineralogy}

Since several South African and other studies have shown the large influence of the mineralogical composition of the clay fraction of soils on soil physical conditions (e.g. Stern, 1990; Bloem, 1992), clay mineralogical analyses were done on the soils (Table 4). The analyses were done at the ARC-ISCW in Pretoria according to the X-ray diffraction method described by Bühmann et al. (1996), using a Philips diffractometer and graphite monochromated Co K $\alpha$ radiation, generated at 40 $\mathrm{mA}$ and $45 \mathrm{kV}$. Specimens were scanned from 2 to $35^{\circ} 2 \theta$.

\section{Soil chemical properties}

The methodologies applied for the determination of the soil chemical properties were (AgriLASA, 1990; Jackson, 1958):

- $\mathrm{pH}-\mathrm{a} 1$ to 2.5 mass of soil to water solution was used $\left(\mathrm{pH}-\mathrm{H}_{2} \mathrm{O}\right)$;

- Exchangeable cations ( $\mathrm{Na}, \mathrm{K}, \mathrm{Ca}, \mathrm{Mg})$ $\mathrm{NH}_{4} \mathrm{OAc}, 1 \mathrm{M}$ method: at $\mathrm{pH}$, an extraction ration of 1:10 and shaken for $30 \mathrm{~min}$;

- S-value = sum of exchangeable cations $(\mathrm{Na}, \mathrm{K}$, $\mathrm{Ca}, \mathrm{Mg})$ in $\mathrm{cmol}(+) / \mathrm{kg}$;

- CEC (Cation Exchange Capacity) - The following is used to exchange the cations: $1 \mathrm{M}$ $\mathrm{NH}_{4} \mathrm{OAc}, \mathrm{pH} 7 ; 0.2 \mathrm{M} \mathrm{NH}_{4} \mathrm{OAc}, \mathrm{pH} 7 ; 0.5 \mathrm{M} \mathrm{LiCl}$;

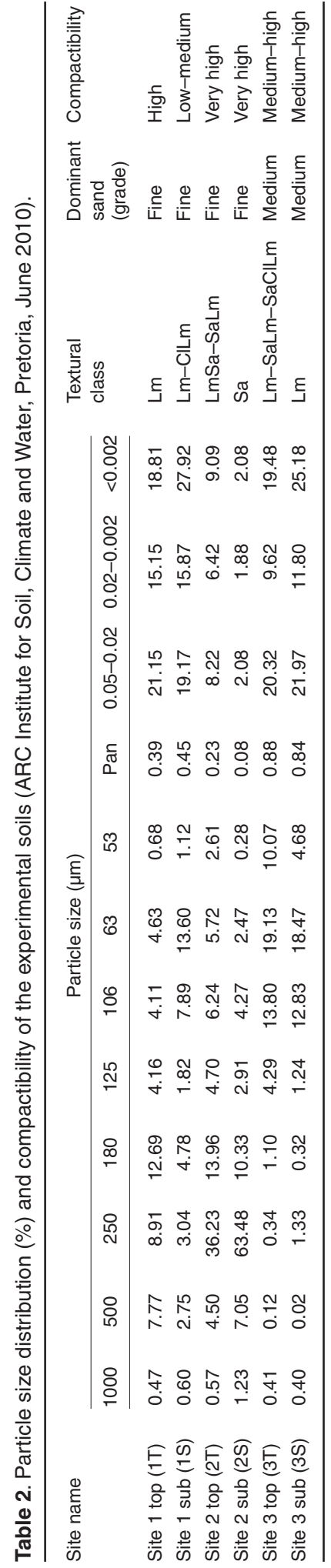


Table 3. Sand fraction sorting (sorting, skewness and kurtosis) of experimental soils (University of Pretoria, Department of Geology, August 2010).

\begin{tabular}{|c|c|c|}
\hline Soil & Phi value & Class \\
\hline $1 \mathrm{~T}$ & 1.25 & Poor \\
\hline $1 S$ & 1.15 & Poor \\
\hline $2 \mathrm{~T}$ & 1.02 & Poor \\
\hline $2 S$ & 0.61 & Moderately well \\
\hline 3Т & 0.62 & Moderately well \\
\hline $3 S$ & 0.62 & Moderately well \\
\hline \multicolumn{3}{|c|}{ Relevant class limits } \\
\hline Class & & Class limits \\
\hline \multirow{3}{*}{\multicolumn{2}{|c|}{$\begin{array}{l}\text { Moderately well sorted } \\
\text { Moderately sorted } \\
\text { Poorly sorted }\end{array}$}} & $0.50-0.70$ \\
\hline & & $0.70-1.00$ \\
\hline & & $1.00-2.00$ \\
\hline
\end{tabular}

- Organic matter $(\% \mathrm{C})$ - readily oxidizable organic matter is determined by oxidation with potassium dichromate (Walkey Black method).

\section{Statistical analyses}

One-way analysis of variance (ANOVA) (SPSS V. $19.0^{\circledR}$ ) was performed for each of the three sites, to compare the average root area fractions across the five (including the control) different tyre pressures. Pairwise comparisons, least significant differences (LSD), were performed post hoc to determine between which tyre pressures the statistically significant differences occurred.

Two-way analysis of variance (ANOVA) (SPSS V.19.0 ${ }^{\circledR}$ ), without interactions and post hoc pair- wise comparisons were performed to compare the mean root densities across the three sites and five tyre pressures. The level of significance was $\alpha=$ 0.05 .

\section{RESULTS}

The average gravimetric soil water content values at the trial sites decreased with soil depth. There were also differences in the average soil water content between the trial sites, with the LW site with a higher water content, followed by the Camp site and the River site. However, more important for the purpose of this study is the average soil water content at field capacity (standard reference water content). The average soil water content at field capacity was highest at the the LW site, followed by the Camp site and the River site (Table 1).

The particle-size distribution of the three trial sites differ substantially in respect to clay and silt contents, which may effect soil compaction (Table 2). Sites 1 and 3 were similar with regard to clay content (top- and subsoil), and increases in clay content from topsoil to subsoil. The soils at the three sites differ significantly in regard to their fine sand content, with Site 1 much lower fine sand content than Site 3. Site 2 in contrast to Sites 1 and 3 is classified as sandy.

The degree of sorting of the sand fraction in the soils is also an important factor to consider with regards to susceptibility to compaction (Table 3; Fig. 4). At Site 1 sorting of the sand fraction of both the topsoil and subsoil is poor. At Site 3 sorting is moderateley well, as indicated by sharp increases

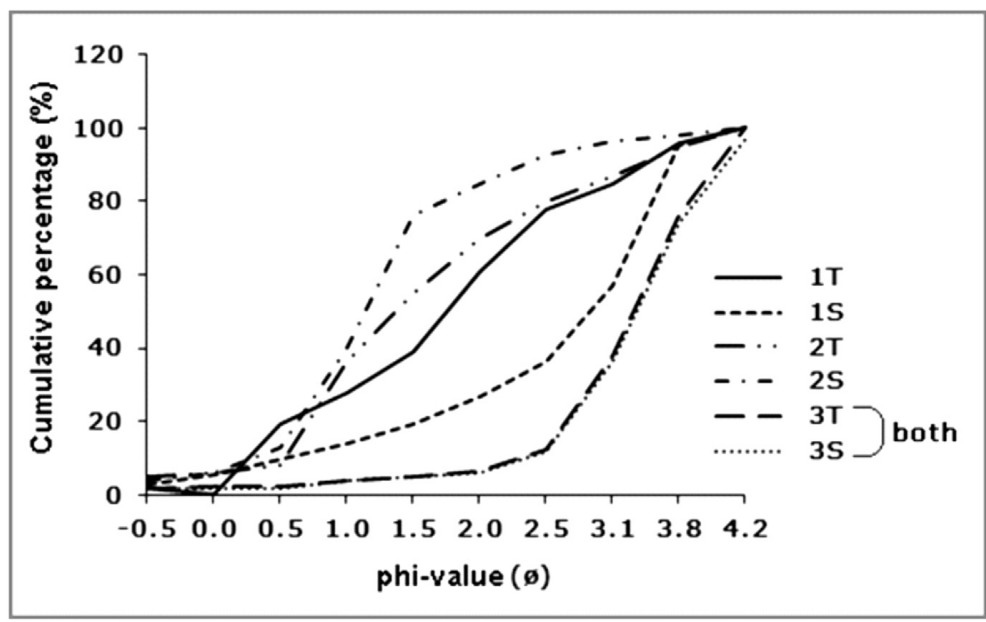

Fig. 4. Cumulative phi-value curves for experimental soils (University of Pretoria, Department of Geology, August 2010). 
Table 4. Clay mineralogical analysis of experimental soils (ARC, Institute for Soil, Climate and Water, Pretoria, June 2010). Six treatments.

\begin{tabular}{lccccccc}
\hline Site name & $\begin{array}{c}\text { Quartz } \\
\text { (Qz) }\end{array}$ & $\begin{array}{c}\text { Smectite } \\
\text { (St) }\end{array}$ & $\begin{array}{c}\text { Kaolinite } \\
\text { (Kt) }\end{array}$ & $\begin{array}{c}\text { Mica } \\
(\mathrm{Mi})\end{array}$ & $\begin{array}{c}\text { Talc } \\
(\mathrm{Tc})\end{array}$ & $\begin{array}{c}\text { Feldspar } \\
(\mathrm{Fs})\end{array}$ & $\begin{array}{c}\text { Hematite } \\
(\mathrm{Hm})\end{array}$ \\
\hline Camp (1T,1S) & 35 & 28 & 29 & 8 & 0 & 0 & 0 \\
River (2T,2S) & 41 & 13 & 10 & 22 & 5 & 9 & 0 \\
LW (3T,3S) & 15 & 30 & 41 & 11 & 1 & 0 & 2 \\
\hline
\end{tabular}

Table 5. Soil chemical properties of experimental soils [cmol $(+) / \mathrm{kg}](\mathrm{ARC}$, Institute for Soil, Climate and Water, Pretoria, June 2010).

\begin{tabular}{|c|c|c|c|c|c|c|c|c|}
\hline Site name & $\mathrm{pH}\left(\mathrm{H}_{2} \mathrm{O}\right)$ & $\mathrm{Na}$ & $\mathrm{K}$ & $\mathrm{Ca}$ & $\mathrm{Mg}$ & S-value & CEC & $\begin{array}{c}\% \text { C } \\
\text { (topsoil) }\end{array}$ \\
\hline $1 \mathrm{~T}$ & 6.20 & 0.33 & 0.40 & 6.65 & 4.05 & 11.43 & 13.91 & 1.12 \\
\hline $1 S$ & 6.69 & 0.40 & 0.29 & 10.57 & 5.77 & 17.02 & 17.42 & \\
\hline $2 \mathrm{~T}$ & 7.97 & 0.07 & 0.23 & 6.18 & 2.86 & 9.34 & 8.32 & 1.15 \\
\hline $2 S$ & 8.10 & 0.02 & 0.06 & 2.23 & 1.27 & 3.58 & 2.59 & \\
\hline $3 T$ & 6.91 & 0.47 & 0.46 & 7.49 & 4.21 & 12.63 & 13.33 & 1.06 \\
\hline $3 S$ & 5.61 & 0.13 & 0.16 & 10.53 & 5.98 & 16.79 & 19.02 & \\
\hline
\end{tabular}

in cumulative curves between phi values of 2.5 and 3.8. At Site 2 the topsoil (2T) is moderately sorted and the subsoil (2S) moderately well.

The soils at Sites 1 and 3 are characterized by dominant quantities of kaolinite as well as significant quantities of smectite. This combination of kaolinite and smectite makes these soils highly prone to disaggregation and compaction (Stern, 1990) (Table 4). The soils at Sites 1 and 2 also have significant quantities of quartz in their clay fractions, which make them extremely prone to diaggregation and subsoil compaction (Laker, 2004).

All soils in this study have low organic matter contents (Table 5), which would increase their vulnerability to disaggregation and compaction (Nortjé et al., 2012). Relatively high exchangeable sodium contents or lopsided $\mathrm{Mg}: \mathrm{Ca}$ ratios would also increase the vulnerability of soils to disaggregation (Bloem \& Laker, 1994), but these are not problems in the soils of the present study (Table 5).

\section{Root densities}

The results of the one-way ANOVA performed for each one of the trial sites (Sites 1,2 and 3) indicated that at Site 1 the mean root density fractions differed significantly across at least two tyre pressures $\left(F_{(4,10)}=465.27, P<0.0001\right)$. Similar results were obtained for the mean root density fractions across tyre pressure at Site $2\left(F_{(4,10)}=\right.$
307.23, $P<0.0001)$ as well as at Site $3\left(F_{(4,10)}=\right.$ 434.94, $P<0.0001$ ).

In Table 6, the mean root densities per site are given and the results from the post hoc comparisons of the one-way ANOVA across tyre pressure are represented in the superscripts by letters of the alphabet. There is a clear trend of decreasing root density fractions at all three trial sites as tyre pressure increases in the order 80, 160, 240 and $320 \mathrm{kPa}$.

At Site 1 the mean root density fractions at all four tyre pressures $(80,160,240$ and $320 \mathrm{kPa})$ differed significantly from the mean root density fractions at control level. Although the mean root density fractions differed significantly across 80 and $240 \mathrm{kPa}$, and also across 80 and $320 \mathrm{kPa}$, the

Table 6. Post hoc comparisons of root densities across tyre pressures between the three sites.

\begin{tabular}{|c|c|c|c|c|}
\hline \multirow{2}{*}{$\begin{array}{l}\text { Tyre pressure } \\
(\mathrm{kPa})\end{array}$} & \multirow[b]{2}{*}{ Site: } & \multicolumn{3}{|c|}{ Mean root densities (\%)* } \\
\hline & & 1 & 2 & 3 \\
\hline Control & & $2.38^{a}$ & $2.42^{\mathrm{a}}$ & $3.63^{a}$ \\
\hline 80 & & $0.60^{\mathrm{b}}$ & $2.12^{\mathrm{ab}}$ & $2.22^{\mathrm{a}}$ \\
\hline 160 & & $0.46^{\mathrm{bc}}$ & $1.37^{\mathrm{b}}$ & $2.90^{\mathrm{a}}$ \\
\hline 240 & & $0.32^{\mathrm{cd}}$ & $0.35^{b}$ & $0.35^{\mathrm{ab}}$ \\
\hline 320 & & $0.16^{d}$ & $0.77^{b}$ & $0.27^{b}$ \\
\hline
\end{tabular}

*Mean root densities with the same superscript letter do not differ significantly, while those with different letters, differ significantly at the $5 \%$ level of significance. 
Table 7. Descriptive statistics of root density fraction in the top $430 \mathrm{~mm}$ soil layer for sites 1,2 and 3 , in the Kruger National Park, S.A.

\begin{tabular}{|c|c|c|c|c|c|c|c|}
\hline \multirow[t]{2}{*}{ Site } & \multirow{2}{*}{$\begin{array}{l}\text { Tyre pressure } \\
\qquad(\mathrm{kPa})\end{array}$} & \multicolumn{5}{|c|}{ Root density fraction (\%) } & \multirow[b]{2}{*}{$\begin{array}{c}\text { LSD } \\
(P<0.05)\end{array}$} \\
\hline & & $\begin{array}{c}\text { Mean } \\
\text { deviation }\end{array}$ & Standard & Minimum & Maximum & Range & \\
\hline \multirow[t]{5}{*}{1} & Control & 2.38 & 0.10 & 2.30 & 2.50 & 0.20 & \\
\hline & 80 & 0.60 & 0.05000 & 0.55 & 0.65 & 0.10 & \\
\hline & 160 & 0.46 & 0.06000 & 0.40 & 0.52 & 0.12 & 0.128 \\
\hline & 240 & 0.31 & 0.08021 & 0.24 & 0.40 & 0.16 & \\
\hline & 320 & 0.16 & 0.05686 & 0.10 & 0.21 & 0.11 & \\
\hline \multirow[t]{5}{*}{2} & Control & 2.42 & 0.12530 & 2.30 & 2.55 & 0.25 & \\
\hline & 80 & 2.12 & 0.10817 & 2.00 & 2.21 & 0.21 & \\
\hline & 160 & 1.37 & 0.07506 & 1.30 & 1.45 & 0.15 & 0.152 \\
\hline & 240 & 0.35 & 0.05508 & 0.30 & 0.41 & 0.11 & \\
\hline & 320 & 0.76 & 0.03512 & 0.73 & 0.80 & 0.07 & \\
\hline \multirow[t]{5}{*}{3} & Control & 3.63 & 0.20817 & 3.40 & 3.80 & 0.40 & \\
\hline & 80 & 2.21 & 0.12583 & 2.10 & 2.35 & 0.25 & \\
\hline & 160 & 2.90 & 0.11240 & 2.78 & 3.00 & 0.22 & 0.229 \\
\hline & 240 & 0.35 & 0.05568 & 0.30 & 0.41 & 0.11 & \\
\hline & 320 & 0.27 & 0.06506 & 0.20 & 0.33 & 0.13 & \\
\hline
\end{tabular}

mean density fractions did not differ significantly between 240 and $320 \mathrm{kPa}$. A significant difference was also observed between 160 and $320 \mathrm{kPa}$.

Site 2 presents a different picture: The mean root density fractions at control level did not differ significantly from the man density fraction at $80 \mathrm{kPa}$, but was significantly different from the mean density fractions at 160, 240 and $320 \mathrm{kPa}$. Lastly, there was no significant difference between any two mean density fractions at 80, 160, 240 and $320 \mathrm{kPa}$.

The mean root density fractions at Site 3 did not differ significantly across control, 80, 160 and $240 \mathrm{kPa}$. However, the mean density fractions at these tyre pressures all differed significantly from the mean density fractions at $320 \mathrm{kPa}$.

Descriptive statistics for the root density fractions in the top $430 \mathrm{~mm}$ soil layer for sites 1, 2 and 3, in the Kruger National Park, South Africa, appear in Table 7.

The two-way ANOVA performed indicated that the mean root density fractions, as indicators of root development, differed significantly across at least two treatments (control and four tyre pressures) and/or sites (Sites 1,2 and 3) where driving was done on dry soil at the $5 \%$ level of significance $\left(F_{(6,7)}=32.67, P<0.0001\right.$ for the corrected model; $F_{(2,11)}=18.77, P<0.0001$ for the
Site factor and $F_{(4.9)}=39.62, P<0.0001$ for the factor Tyre pressure).

Post hoc pairwise comparisons showed that the mean root density fractions differed significantly at the $5 \%$ level across all three sites $(P$-value $=0.001$ for Sites 1 and 2; $P$-value $<0.0001$ for Sites 1 and 3 and $P$-value $=0.013$ for Sites 2 and 3 . The mean root density fractions differed significantly across all the tyre pressures with the exception of 80 and $160 \mathrm{kPa}(P$-value $=0.774)$ and 240 and $320 \mathrm{kPa}$ $(P$-value $=0.800)$.

Since the two-way ANOVA indicated that there were significant differences in the mean root density fractions across site and tyre pressure, one-way ANOVAs were performed to compare the mean root density fractions across tyre pressure per site.

\section{Site 1}

As can be seen in Table 7, the root fraction percentage in the control was much (4.0 to 14.6 times) higher than under the wheel tracks at all tyre pressures used. The differences between the control and the four tyre pressures were significant $(P$-value $<0.000015)$. Mean root fraction percentages under the wheel tracks differed significantly across all tyre pressures $(P$-value $<0.000015)$, except between 80 and $160 \mathrm{kPa}(P$-value $=0.406)$; 160 and $240 \mathrm{kPa}(P$-value $=0.369)$ and 240 and 


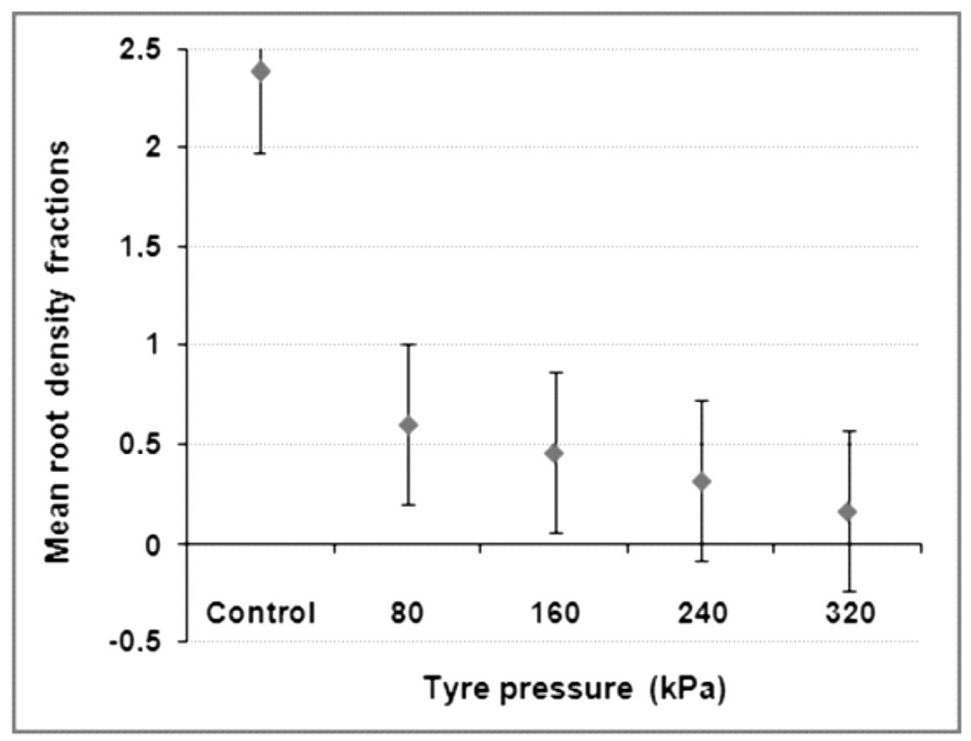

Fig. 5. Root density fraction vs tyre pressure for Site 1.

$320 \mathrm{kPa}(P$-value $=0.277)$. The mean root fractions decreased in the order $80 \mathrm{kPa}>160 \mathrm{kPa}>$ $240 \mathrm{kPa}>320 \mathrm{kPa}$ (Figs 5 and 6).

\section{Site 2}

There was a more gradual decreasing trend in mean root density fraction as the tyre pressure increased at Site 2 (Figs 7 and 8). The differences between the control and the four tyre pressures were significant $(P$-value $<0.0001$, except between control and $80 \mathrm{kPa}$ and $240 \mathrm{kPa}(P$-value $=0.017)$ and $320 \mathrm{kPa}(P$-value $=0.002)$. The mean root density fraction for the control was similar to that for Site 1. The mean values at 80 and $160 \mathrm{kPa}$ tyre pressures were much higher than that of Site 1. The differences between $80 \mathrm{kPa}$ and $160 \mathrm{kPa}$ and

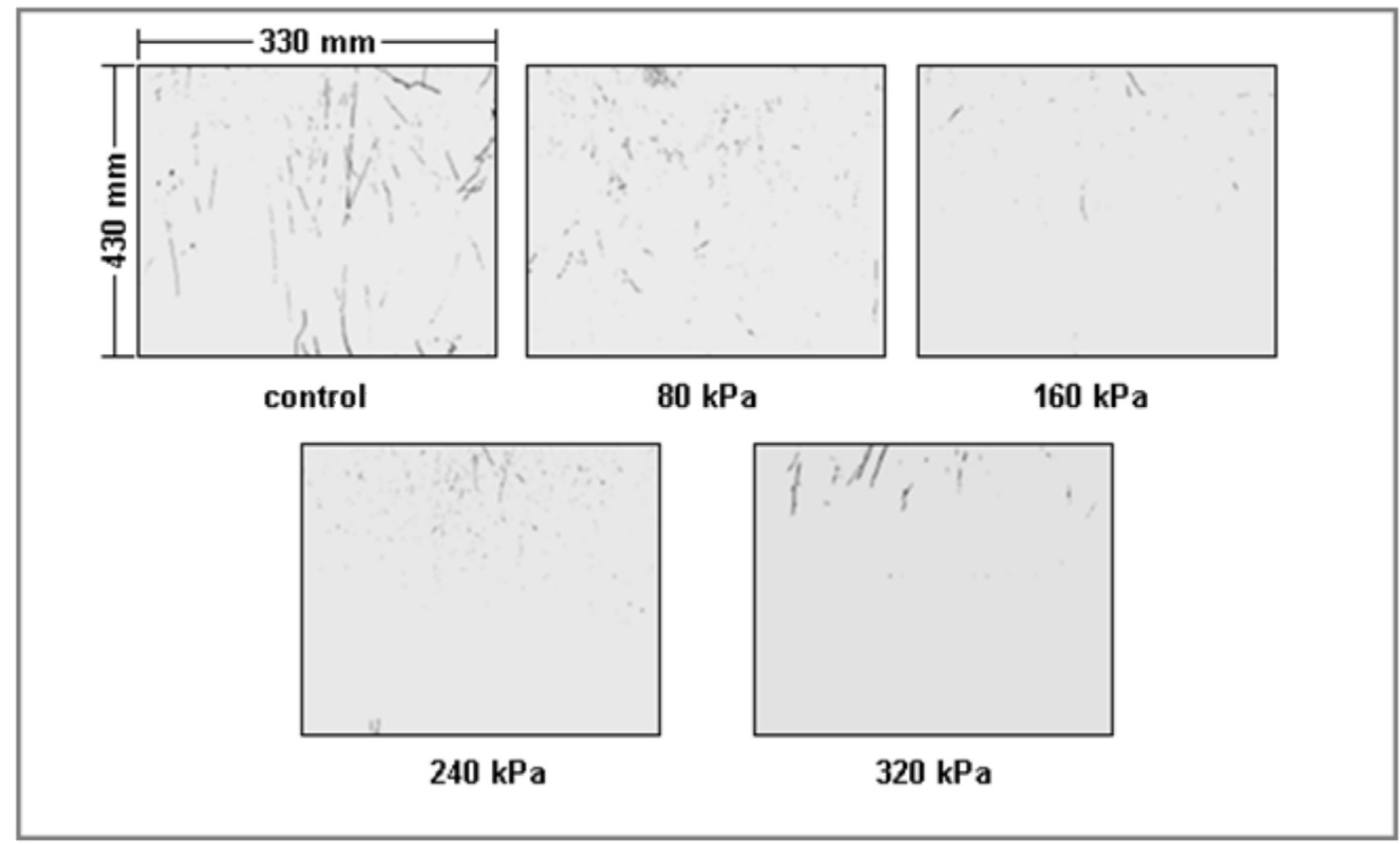

Fig. 6. ImageJ images of root density distributions in the top $430 \mathrm{~mm}$ for Site 1. 


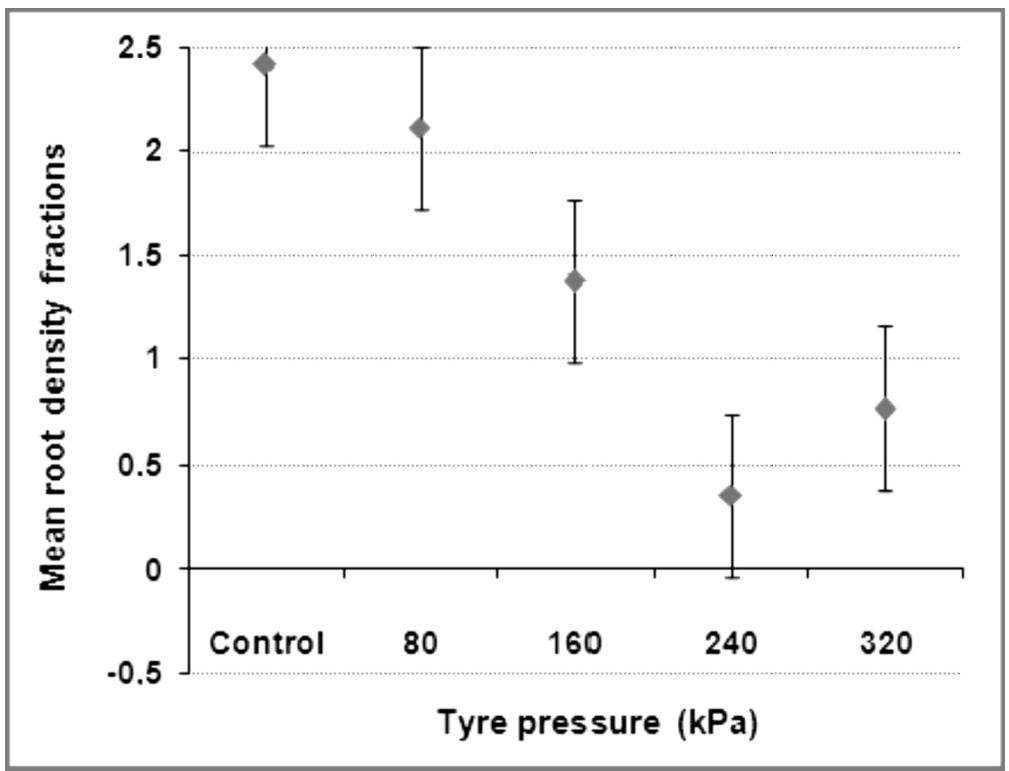

Fig. 7. Root density fraction vs tyre pressure Site 2.

between $160 \mathrm{kPa}$ and $240 \mathrm{kPa}$ (and $320 \mathrm{kPa}$ ) were significant. The sizes of the root density fractions for the different tyre pressures were $80 \mathrm{kPa}>$ $160 \mathrm{kPa}>320 \mathrm{kPa}>240 \mathrm{kPa}$ (note the reverse order of the latter two). The decrease between the control and $80 \mathrm{kPa}$ was more gradual compared with Site 1.

\section{Site 3}

There was a gradual decreasing trend between root density fraction and tyre pressure at Site 3 , which was similar to Site 2 (Figs 9 and 10). The differences in root fraction between the control and all four tyre pressure treatments were significant $(P$-value $<0.0001)$ (Table 7$)$. The mean root

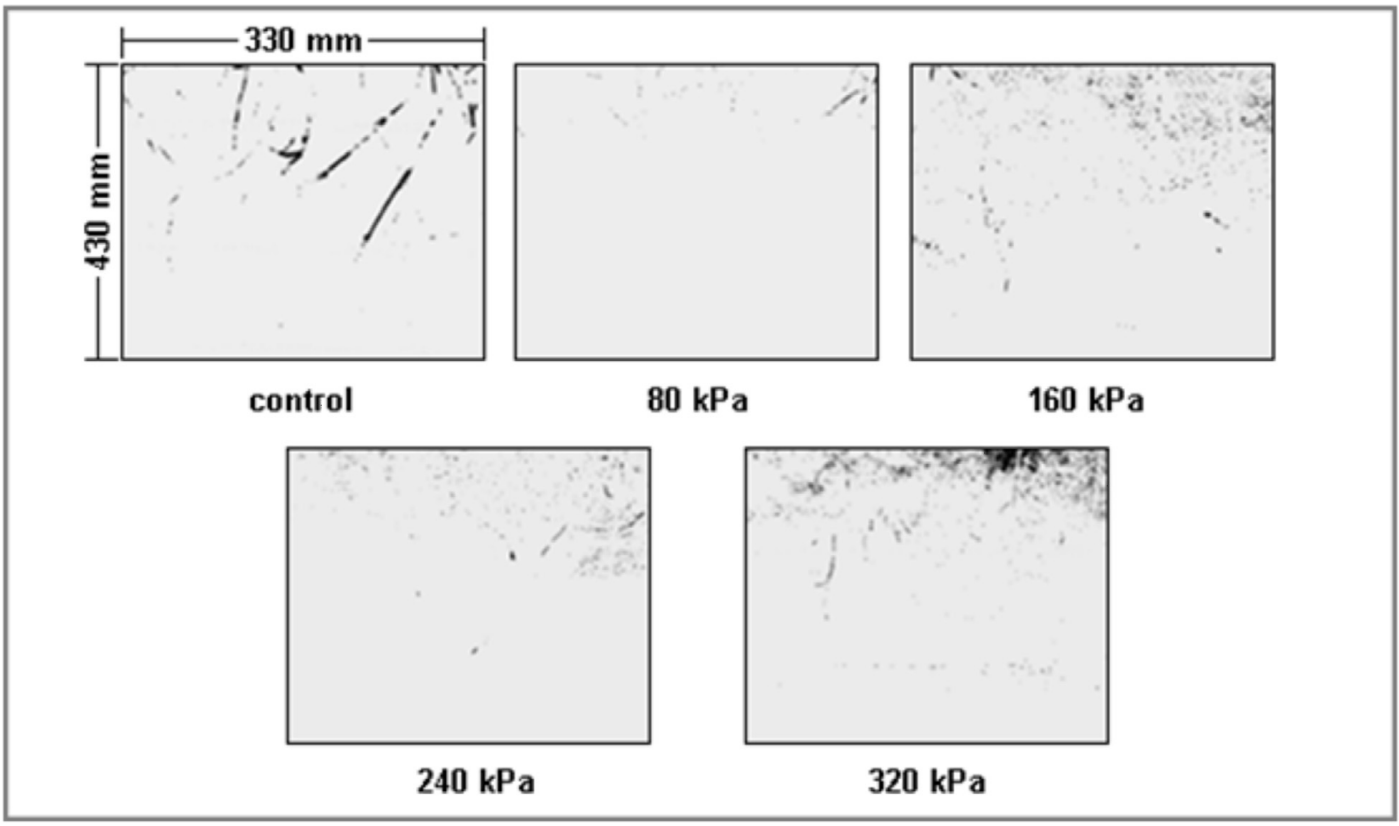

Fig. 8. ImageJ images of root density distributions in the top $430 \mathrm{~mm}$ for Site 2. 


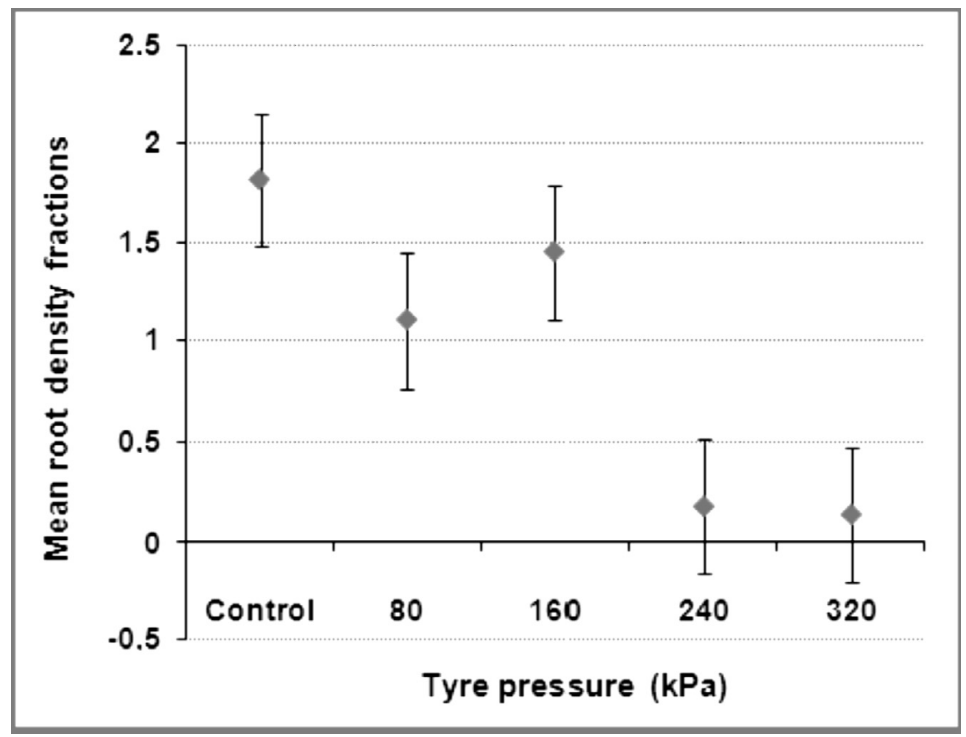

Fig. 9. Root density fraction vs tyre pressure for Site 3.

density fractions between the four tyre pressures differed significantly across all tyre pressures $(P$-value $<0.0001$, except between 80 and $160 \mathrm{kPa}$ where the $P$-value was 0.001 ). There was no significant difference in the mean root density fractions of 240 and $320 \mathrm{kPa}(P$-value $=1.000)$. The sizes of the mean root density fractions for the different tyre pressures were in the order $160 \mathrm{kPa}>80 \mathrm{kPa}>240 \mathrm{kPa}=320 \mathrm{kPa}$. For this type, the root density fractions for the control and at $160 \mathrm{kPa}$ tyre pressure were higher than those for the controls of Sites 1 and 3. The value for $80 \mathrm{kPa}$ tyre pressure was similar to those for the controls for Sites 1 and 2 and the $80 \mathrm{kPa}$ value of Site 2 . In contrast to the relatively high root density fractions at the two low tyre pressures, the values at the two high tyre pressures were very low, like for the two other soils.

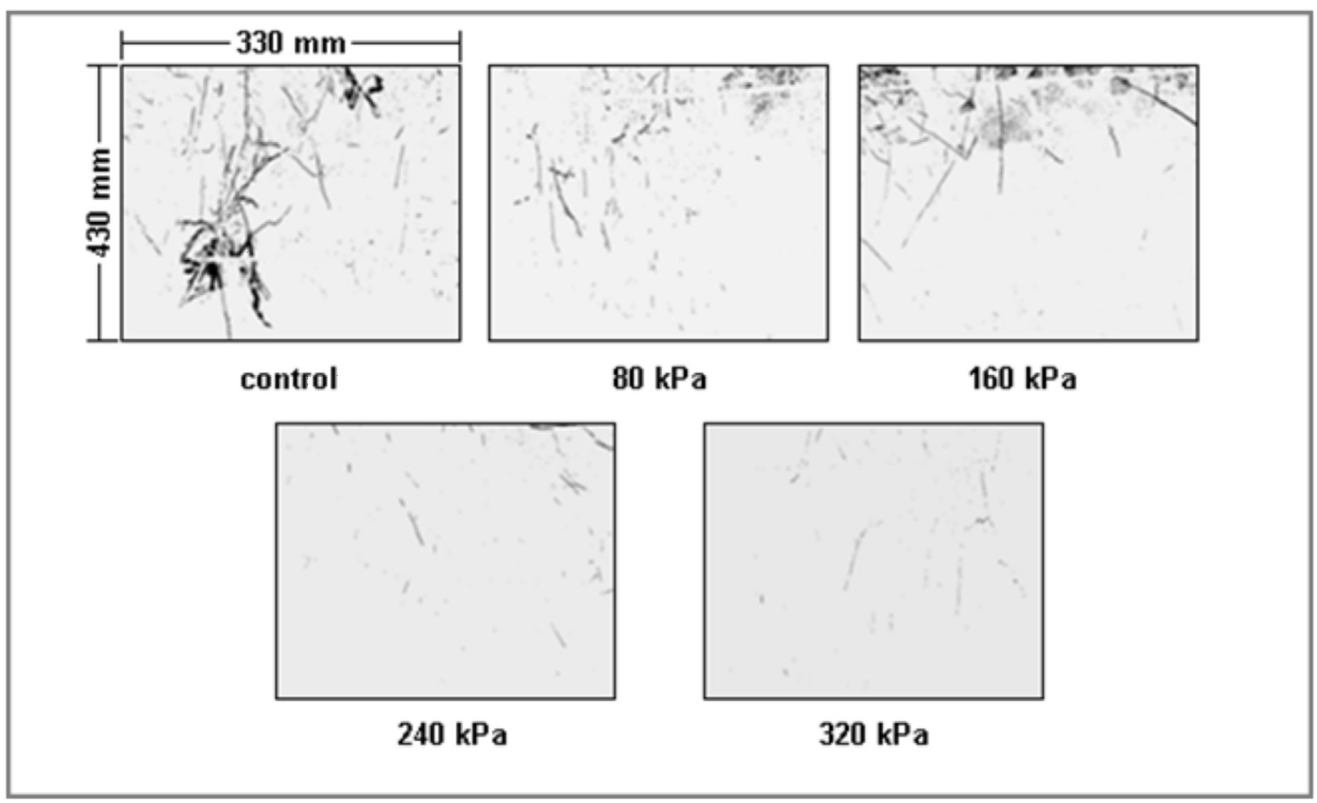

Fig. 10. ImageJ images of root density distributions in the top $430 \mathrm{~mm}$ for Site 3. 


\section{DISCUSSION}

\section{Compactibility of the soils}

The Oakleaf soils at Sites 1 and 3 are similar in regard to clay content (including similar topsoil clay contents, similar subsoil clay contents, and similar increases in clay content from topsoil to subsoil), and silt content (being high relative to the values for most South African soils, but common for Oakleaf soils).

Particle size distribution or soil texture is closely related to bulk density and is an important indicator of a soil's susceptibility to compaction (Reed, 1983). Van der Watt (1969) found in a study of a group of soils that of various factors which may influence soil compactibility, particle-size distribution was the most important. The particle size distribution of the three trial sites differed substantially in respect to aspects that may affect soil compaction (Table 2).

These soils differ substantially in regard to their fine sand content, a very important factor regarding susceptibility to soil compaction (Laker, 2001; Bennie \& Burger, 1988). The soil at Site 1, especially the topsoil (1T), had a much lower fine sand $(<100 \mu \mathrm{m})$ content (26.7 and $29.7 \%$ for top- (1T) and subsoil (1S), respectively) than that for top(3T) and subsoil (3S) at Site 3 (49.8 and 38.4\%, respectively). This means that the fine sand plus silt content of the soil at Site 1 was more than $60 \%$ and at Site 3 more than $70 \%$, with the topsoil nearly $80 \%$. Serious compaction is normally expected in soils with more than $50 \%$ fine sand plus silt, especially if silt is more than $20 \%$, and less than 35\% clay (Laker, 2001). Expressed as a fraction of the sand content of the soils, the fine sand proportions were about $60 \%$ for the topsoil at Site 1 and $82 \%$ for the subsoil, compared with more than $95 \%$ for both the top- and subsoils at Site 3.

In contrast to the others, the soil at Site 2 was a sandy soil. The subsoil (2S), with only $2 \%$ clay and $3 \%$ silt, was classified as having pure sand texture. The sand fraction was also much coarser than at the other two sites, being dominated by medium sand and with relatively little fine sand.

The degree of sorting of the sand fraction of a soil is also a factor to consider. At Site 1 sorting in the sand fraction of both the topsoil and subsoil was poor, but close to moderate due to fairly sharp increases in parts of the cumulative phi value curves (Table 3 and Fig. 4). At Site 3, sorting was moderately well, as indicated by sharp increases in cumulative curves between phi values of 2.5 and 3.8. At Site 2 the topsoil (2T) was very close to moderately sorted and the subsoil moderately well. Henning et al. (1986) found that soils with moderately sorted sand fractions are more prone to soil compaction than soils with poorly sorted sand fractions. Moolman \& Weber (1978) found extreme compaction of well-sorted fine sandy soils in the southwestern Cape of South Africa. They did not expect such well-sorted soil to be prone to compaction, but it nonetheless happenned. They expected that a well-graded soil, with a good mixture of different particle sizes would be a prerequisite for severe compaction. Bennie \& Burger (1988) described the majority of soils that are susceptible to compaction at Vaalharts according to the following words: '...characterised by a high fine sand fraction, low clay and organic matter content, single grain to weakly massive structure and particle size with good sorting'. Thus, sorting of their sand fractions could contribute to making the soils at the trial sites more vulnerable to compaction, although it is evident that sorting alone does not give complete explanation for the vulnerability of soils to compaction.

Clay mineralogy plays an important role in determining the susceptibility of soil to disaggregation of aggregates, and thus also in its vulnerability to crusting and erosion (Stern, 1990; Bloem, 1992; Bühmann et al., 1996; Rapp, 1998). This would also be the case with vulnerability to compaction. Usually soils with clay fractions dominated by smectite are considered the most vulnerable to dispersion and disaggregation, while those dominated by kaolinite are considered to be quite stable (Rapp, 1998). However, in South African studies, it has been found that soils in which kaolinite is dominant, but occurs in combination with significant amounts of smectite, are very vulnerable to disaggregation (Stern, 1990; Bloem \& Laker, 1994) (Table 4). On this evidence, the Oakleaf soils of Sites 1 and 3 should be highly prone to disaggregation and compaction (Table 3). It has been found that soils with high quartz contents in their clay fractions are found widespread in South Africa (Laker, 2004). In addition, soils with high quartz contents in their clay fractions are extremely prone to disaggregation, crusting and erosion (Bühmann et al., 1996) and also to sub-surface compaction (Moolman \& Weber, 1978). This would then be an important factor at especially Sites 1 and 2.

It would thus seem that a combination of unfavourable particle size distribution and clay mineral- 
ogical composition of the soils in the study could be key factors aggravating their potential vulnerability to both crusting and subsurface compaction.

\section{Effects of ORD on root density fractions}

For all three soils, the root density fractions for the controls were significantly higher than under the tracks of all four tyre pressures (Table 7). At Site 1 the difference between the control and under the tracks was significant for all tyre pressures. At Sites 2 and 3, which had some vegetative cover, the effects at the two lower tyre pressures were not as damaging as at Site 1. At all three sites the two higher tyre pressures had very serious negative impacts on the root density fractions, irrespective of vegetative cover at the time of driving. These include the tyre pressure at which game drive vehicles normally operate (approximately $240 \mathrm{kPa}$ ). This correlates very well with the findings in another part of this study, which indicated that the amount of soil compaction increased with increased tyre pressure (Nortjé, 2014).

The mean root densities differed significantly across all three sites and some of the tyre pressures (Table 6). These results indicated that there were also differences between the root density fractions at specific tyre pressures, between sites.

As tyre pressure increased, the rooting depth decreased. This is shown for all three sites in the profile photographs (Figs 6, 8 and 10), where most roots were limited to the top part of the soil profiles, most notably at the higher tyre pressures at Site 3. This correlates well with the findings of Taylor et al. (1966), Bennie (1972), Burger et al. (1979) and Bennie \& Burger (1979).

Taylor et al. (1966) reported a similar relationship between penetrometer soil strength and percentage of cotton taproots penetrating through cores of four soils. In a study by Greacen \& Gerard (unpublished data reported in Greacen \& Sands 1980) on the effects of soil strength on frequency of rooting of radiata pine (Pinus radiata), the authors also found a similar relationship as in our study.

Taylor \& Gardner (1963) showed a similar linear relationship as in Site 2 and 3, between root penetration and soil strength in a study of cotton seedling tap root penetration as influenced by soil water, bulk density and soil strength.

Although above-ground vegetative cover was not quantified at the sites, observations indicated good relationships between root development, soil texture and above-ground vegetative cover. Soil crusting and sub-soil compaction was much more severe at site 2, than at sites 1 and 3 (Nortjé et al., 2012), and these impact differences are also reflected in the root density distributions (Figs 6, 8 and 10). A shallower root system will make plants more vulnerable to drought, because utilization of water stored in the subsoil is very important to plants.

A very important finding of this study is that ORD has strong negative impacts on soil crusting, subsoil compaction and, consequently, root development or root density distribution. This negative impact was even during dry soil conditions. It is well known and literature shows that soils with higher water contents (especially those at just below field capacity) are much more susceptible to soil crusting and sub-soil compaction than soils with lower water contents (SASTA, 2001; Bennie, 1972; Henning et al., 1986; Nortjé et al., 2012). Therefore it would be expected that if the root density study was done under wet conditions (higher soil water content), the impact on root density distribution would have been much worse.

\section{CONCLUSION}

Results indicated that root penetration, and therefore, root area distribution was reduced drastically as tyre pressure increased. This reaffirms previous research showing that higher tyre pressures cause higher sub-soil compaction than lower tyre pressures (SASTA, 2001). Driving at low tyre pressures should be stipulated as a prerequisite when off-road guidelines are developed. Crusting has serious long-lasting effects like inhibiting root growth (Laker \& Vanassche, 2001), germination and seedling emergence, the latter especially of small-seeded plants like grasses, and thus waterand nutrient uptake.

Indications therefore, from this study are that the specific photographic method (ImageJ) evaluated during this study for quantifying the relationships between tyre pressure and root development, is suitable for studies on similar soil types and soil moisture regimes. It is a relatively quick method, accurate and very practical for use in protected areas.

\section{ACKNOWLEDGEMENTS}

The authors would like to thank Wilderness Safaris/Safari Adventure Company for all the support throughout the research and for believing in the project. We are extremely grateful to Paula Nortjé for the editing of this manuscript. We thank the three reviewers, the Editor in Chief and Assis- 
tant Editor for constructive and helpful comments to improve the manuscript. Thank you also to Michelle Louw for invaluable help with the field trials and Joyce Jordaan for the statistical analyses.

\section{REFERENCES}

AgriLASA (1990). Handbook of standard soil testing methods for advisory purposes. Pretoria, South Africa: Agricultural Laboratory Association of South Africa.

Akama, J.S. (1997). Tourism Development in Kenya. International Journal of Tourism Research, 3, 95-105

Akama, J.S. (1999). Marginalization of the Masai in Kenya. Annals of Tourism Research, 26, 716-718

Annandale, J.G., Stirzaker, R.J., Singels, A., van der Laan, M. \& Laker, M.C. (2011). Irrigation scheduling research: South African experiences and future prospects. Water $S A, 37,751-763$.

Barley, K.P., \& Greacen, E.L. (1967). Mechanical resistance as a soil factor influencing the growth of roots and underground shoots. Advances in Agronomy, 19, $1-43$.

Bekker, T.F. (2007). Efficacy of water-soluble silicon for control of Phytophtora cinnamomi root rot of avocado. (Unpublished M.Sc. thesis). Pretoria, South Africa: University of Pretoria.

Bengough, A.G., Mckenzie, B.M., Hallet, P.D. \& Valentine, T.A. (2011). Root elongation, water stress and mechanical impedance: a review of limiting stresses and beneficial root tip traits. Journal of Experimental Botany, 62, 59-68.

Bennie, A.T.P. (1972). 'n Ondersoeknasekereaspekte van grondsterkte in gronde van die manganoserie. (Unpublished M.Sc. (Agric) thesis). Bloemfontein, South Africa: Universiteit van die Oranje Vrystaat.

Bennie, A.T.P. \& Burger, R.D.T. (1979). Grondverdigtingonderbesproeiing op die Vaalhartsbesproeiingskema. Volume II: Die invloed van grondverdigting op die grond-plant sisteem. Dept. Grondkunde, Verslag, 79/2. Bloemfontein, South Africa: Universiteit van die Oranje Vrystaat.

Bennie, A.T.P. \& Burger, R.D.T. (1988). Penetration resistance of fine sandy soils as affected by relative bark density, water content and texture. Southern African Journal of Plant \& Soil, 5, 5-10.

Bennie, A.T.P. \& Krynauw, G.N. (1985). Causes, adverse effects and control of soil compaction. Southern African Journal of Plant \& Soil, 2, 109-114.

Bhandari, M.P. (1998). Assessing the impact of off-road driving in Masai Mara National Reserve, Narok, Kenya. (Unpublished M.Sc. thesis). Enschede, Netherlands: ITC-International Institute for Aerospace Survey and Earth Sciences.

Bhandari, M.P. (2000). Tourism raised problems in Masai Mara National Park. Narok, Kenya: Kenya Mountain Forum.

Bhandari, M.P. (2014). Is tourism always beneficial? A case study from Masai Mara National Reserve, Narok, Kenya. The Pacific Journal of Science and Technology, 15, 458-483

Bloem, A.A. (1992). Kriteria vir die aanpassing van die ontwerp en bestuur van oorhoofsebesproeiingstel- sels by die infiltreerbaarheid van gronde. (Unpublished M.Sc. thesis). Pretoria, South Africa: University of Pretoria.

Bloem, A.A. \& Laker, M.C. (1994). Infiltrasie onder velden laboratoriumtoestande. Water SA, 20, 133-138.

Bohm, W. (1979). Methods of studying root systems. Berlin, Heidelberg, New York: Springer-Verlag.

Bühmann, C., Rapp, I. \& Laker, M.C. (1996). Differences in mineral ratios between disaggregated and original clay fractions in some South African soils as affected by amendments. Australian Journal of Soil Research, 34, 909-923.

Burger, R.D.T., Bennie, A.T.P., Botha, F.J.P. \& du Preez, C.C. (1979). Grondverdigting onder besproeiing op die Vaalhartsbesproeiingskema. Volume I: Samevattende verslag, 79(1). Bloemfontein, South Africa: Departement Grondkunde, Universiteit van die Oranje Vrystaat.

Cassel, D.K., Ratliff, L.F. \& Ritchie, J.T. (1983). Models for estimating in-situ potential extractable water using soil physical and chemical properties. Soil Science Society of America Journal, 47, 764-769.

Crawley, M. (2000). Investigating the impact of tourism in Kenya. Ottawa, Canada: International Development Research Centre - Project Number 958519.

Du Preez, C.C., Bennie, A.T.P. \& Burger, R.D.T. (1979). Grondverdigting onder besproeiing op die Vaalharts besproeiingskema. Volume 3: Die oorsake en bekamping van verdigting van sanderige besproeiingsgronde, verslag 79 (3). Bloemfontein, South Africa: Departement Grondkunde, Universiteit van die Oranje Vrystaat.

Du Preez, C.C., Bennie, A.T.P. \& Burger, R.D.T. (1981). Invloed van implementverkeer en besproeiing op grondverdigting te Vaalharts. Agrochemophysica, 13, 7-12.

Gertenbach, W.P.D. (1983). Landscapes of the Kruger National Park. Koedoe, 26, 9-121.

Greacen, E.L. \& Sands, R. (1980). Compaction of forest soils - A Review. Australian Journal of Soil Research, 18, 163-189.

Haenn, N.M. (2000). Book Review: Imposing wilderness: Struggles over livelihood and nature preservation in Africa. By Roderick P. Neumann. University of California Press, Berkeley, 1998, pp. 256

Henning, J.A.G., Nel, D.J. \& Harmse, H.J.v.M. (1986). Die invloed van verdigtingspoging, klei- en waterinhoud op verdigting van geselekteerde Hoëveldgronde. Southern Africa Journal of Plant \& Soil, 3, 119-122.

Jackson, M.L. (1958). Soil chemical analysis. Englewood Cliffs, U.S.A.: Prentice-Hall.

Laker, M.C. (2001). Soil compaction: Effects and amelioration. Proceedings of the South African Sugar Technologist's Association 75 (pp. 125-128).

Laker, M.C. (2004). Advances in soil erosion, soil conservation, land suitability evaluation and land use planning research in South Africa, 1978-2003. Southern Africa Journal of Plant \& Soil, 21, 345-368.

Laker, M.C. \& Vanassche, F.M.G. (2001). Alleviation of soil crusting in a citrus orchard by means of a coalderived humic product. Programme and Extended Abstracts, Joint Congress, Soil Sci. Soc. S. Afr., Pretoria January 2001 (pp. 265-266). 
Martino, D.L. \& Shaykewich, C.F. (1993). Root penetration profiles of wheat and barley as affected by soil penetration resistance in field conditions. Canadian Journal of Soil Science, 74, 193-200.

Merotto, J.R.A. \& Mundstock, C.M. (1999). Wheat root growth as affected by soil strength. Revista Brasileira da Ciência do Solo, 23, 197-202.

Moolman, J.H. \& Weber, H.W. (1978). 'n Ondersoek na die bydrae van die fynsandfraksie tot die verdigbaarheid van fynsandgronde in Suid-Kaapland. Agrochemophysica, 10, 39-46.

Nortjé, G.P. (2005). The impacts of off-road driving and other concessionaire activities on physical soil degradation. (Unpublished M.Phil. thesis). Pretoria, South Africa: University of Pretoria.

Nortjé, G.P. (2014). Studies on the impacts of off-road driving and the influence of tourists' consciousness and attitudes on soil compaction and associated vegetation in the Makuleke Contractual Park, Kruger National Park. (Unpublished Ph.D. thesis). Pretoria, South Africa: University of Pretoria.

Nortjé, G.P., van Hoven, W. \& Laker, M.C. (2012). Factors affecting the impact of off-road driving on soils in an area in the Kruger National Park, South Africa. Environmental Management, 50, 1164-1176.

Ondicho, T.G. (2000). International tourism in Kenya: problems and policy alternatives. Eastern Africa Social Science Research Review (EASSRR) 16, 49-70

Onyeanusi, A.E. (1986). Measurements of impact of tourist off-road driving on grasslands in Masai Mara National Reserve, Kenya: a simulation approach. Environmental Conservation, 13, 325-329

Ottichilo, W.K., de Leeuw, J., Skidmore, A.K., Herbert, H. T.P. \& Said, M.S. (2000). Population trends of large non-migratory wild herbivores and livestock in the Masai Mara ecosystem, Kenya, between 1977 and 1997. African Journal of Ecology, 38, 202-216.

Pafuri Factsheet (2011). Makuleke cultural heritage. Rivonia, South Africa: Information sheet to Pafuri Camp in the Makuleke Contractual Park.

Plaza-Bonilla, D., Cantero-Martínez, C., Ivaro-Fuentes, J. \& Castel, J.L. (2012). Low-cost image analysis method to quantify root surface area. Poster Session. International conference of agricultural engineering, July 8-12. Valencia, Spain.
Rapp, I. (1998). Effects of soil properties and experimental conditions on the rill erodibility of selected soils. (Unpublished Ph.D. thesis). Pretoria, South Africa: University of Pretoria.

Rasband, W. (2011). ImageJ, U.S. National Institutes of Health, Bethesda, Maryland, USA, 1997-2011. Retrieved from http://imagej.nih.gov/ij/ in January 2011.

Reed, A.H. 1983. The erosion risk of compaction. Soil Water, 11, 29-33.

SASTA (South African Sugar Technologist's Association) (2001). Soil compaction workshop proceedings, August 2001. CD-ROM. Mt Edgecombe, Durban.

Schneider, C.A., Rasband, W.S. \& Eliceiri, K.W. (2012). $\mathrm{NIH}$ Image to ImageJ: 25 years of image analysis. Nature Methods, 9, 671-675.

Soil Classification Working Group (1991). Soil classification: a taxonomic system for South Africa. Pretoria, South Africa: Department of Agriculture Development.

Stern, R. (1990). Effects of soil properties and chemical ameliorants on seal formation, run-off and erosion. (Unpublished D.Sc. (Agric) thesis). Pretoria, South Africa: University of Pretoria

Taylor, H.M. \& Gardner, H.R. (1963). Penetration of cotton seedling taproots as influenced by bulk density, moisture content, and strength of soil. Soil Science, 96, 153-156.

Taylor, H.M., Roberson, G.M. \& Parker, J.J. Jr (1966). Soil strength-root penetration relations for medium- to coarse-textured soil materials. Soil Science, 102, 18-22.

Unger, P.W. \& Kaspar, T.C. (1994). Soil compaction and root growth: a review. Agronomy Journal, 86, 759766.

Van der Watt, H.v.H. (1969). Influence of particle size on soil compactibility. Agrochemophysica, 1, 79-86.

Walpole, M.J., Karanja, G.G., Sitati, N.W. \& LeaderWilliams, N. (2003). Wildlife and People: Conflict and Conservation in Masai Mara, Kenya. Proceedings of a workshop series organised by the Durrell Institute of Conservation and Ecology, University of Kent, UK, 13-16 August 2001.

WRB (World Reference Base for Soil Resources) (1998). Rome: Food and Agriculture Organization of the United Nations (FAO). 